\title{
Pola Luka pada Korban Meninggal akibat Kekerasan Tajam yang Diautopsi di Rsup Prof. Dr. R. D. Kandou Tahun 2014
}

\author{
${ }^{1}$ Brenda Karwur, ${ }^{2}$ James Siwu, ${ }^{3}$ Johannis Mallo \\ ${ }^{1}$ Program Studi Pendidikan Dokter Fakultas Kedokteran Universitas Sam Ratulangi Manado \\ ${ }^{2}$ Bagian Ilmu Kedokteran Forensik dan Medikolegal Fakultas Kedokteran Universitas Sam \\ Ratulangi Manado \\ Email: brendakarwur@gmail.com
}

\begin{abstract}
Violence due to sharp objects can cause injuries to the body in the forms of stab wound, incised wound, and chop wound. This study was aimed to determine the pattern of wounds in death victims due to sharp violence at the Forensic Medicine Department of Prof. Dr. R. D Kandou Manado in 2014. This was a retrospective and descriptive study using data of visum et repertum. The results showed that there were 27 autopsied victims killed due to sharp violence. Males (88.4\%) and age of 21-30 years (37\%) were predominant. The most common type of wound was stab wound (76.9\%), followed by chop wound (15.4\%), and incised wound $(7.7 \%)$. Based on the wound location, left chest had the highest percentage (42.4\%). In conclusion, the most common death victims due to sharp objects were males, aged 21-30 years, with stab wound into the left-sided chest.
\end{abstract}

Keywords: wound pattern, sharp violence

\begin{abstract}
Abstrak: Kekerasan akibat benda tajam dapat menyebabkan luka pada tubuh yang dapat berupa luka tusuk, luka iris, dan luka bacok. Penelitian ini bertujuan untuk mengetahui pola luka pada kematian akibat kekerasan tajam di Bagian Ilmu Kedokteran Forensik RSUP Prof. Dr. R. D. Kandou Manado tahun 2014. Jenis penelitian ialah deskriptif retrospektif dengan menggunakan data hasil visum et repertum tahun 2014. Hasil penelitian mendapatkan bahwa jumlah korban meninggal akibat kekerasan tajam yang diautopsi sebanyak 27 korban, didominasi oleh jenis kelamin laki-laki (88,4\%), dan umumnya dari kalangan muda 21-30 tahun (37\%). Berdasarkan jenis luka didapatkan luka tusuk sebesar 76,9\%, luka bacok 15,4\%, dan luka iris $7,7 \%$. Berdasarkan lokasi, luka pada bagian dada kiri memiliki persentase tertinggi yaitu sebesar $42,4 \%$. Simpulan penelitian ini ialah korban meninggal akibat kekerasan tajam yang terbanyak ialah berjenis kelamin laki-laki, kategori usia 21-30 tahun, dengan luka tusuk lokasi pada dada kiri.
\end{abstract}

Kata kunci: pola luka, kekerasan tajam

\section{PENDAHULUAN}

Kekerasan seringkali menjadi bagian dari sebuah perselisihan. Perilaku kekerasan sering menimbulkan bahaya bagi individu itu sendiri maupun orang lain ${ }^{1}$ Kekerasan tajam adalah suatu ruda paksa yang mengakibatkan luka pada permukaan tubuh yang disebabkan oleh benda-benda tajam. Ditinjau dari sifatnya, kekerasan tajam seringkali dilakukan dengan menggunakan benda-benda tajam seperti pisau, kapak, silet dan lainnya. Benda-benda ini kemudian mengakibatkan luka bahkan kematian bagi individu yang terlibat dalam proses kekerasan $^{1}$

Berdasarkan penyebabnya, luka akibat kekerasan tajam disebut juga trauma tajam. Luka akibat kekerasan tajam umumnya mudah dibedakan dari luka yang disebabkan oleh benda tumpul dan luka tembak. Insiden trauma tajam tercatat 500-1500 kasus pertahunnya di Kota Manado dan 
sekitarnya berdasarkan laporan Polresta Manado tahun 2014. Trauma menjadi penyebab kematian nomor 4 di dunia. ${ }^{2}$

Pada akhir tahun 2012 disebutkan oleh wakil kepala Badan Reserse Kriminal Polri Inspektur Jendral Polisi Saud Usmat, setiap 91 detik terjadi suatu kejahatan di Indonesia sepanjang tahun 2012. Bahkan pada tahun 2014 yang lalu laporan aksi kekerasan dengan menggunakan senjata tajam (sajam) yang masuk di Polresta Manado tercatat sebanyak 72 kasus. Hingga periode semester pertama pada tahun 2015 saja sudah tercatat 73 kasus terjadinya tindakan kriminal yang disertai dengan senjata tajam berkaitan dengan mudahnya memperoleh barang berbahaya tersebut dimana-mana ${ }^{3}$

Hal inilah yang kemudian membuat semakin pentingnya Ilmu kedokteran Forensik. Ilmu Kedokteran Forensik adalah salah satu cabang ilmu Kedokteran yang memberikan bantuan pada penyidik untuk mendapatkan salah satu alat bukti baik untuk perkara pidana maupun perkara perdata. Pada beberapa kasus kematian akibat benda tajam di lakukan otopsi untuk mengidentifikasi jenazah forensik. ${ }^{4}$ Berdasarkan latar belakang ini, maka penulis ingin mengetahui pola sebab kematian akibat benda tajam yang diautopsi di Instalasi Kedokteran Forensik RSUP Prof. Dr. R. D. Kandou Tahun 2014.

\section{METODE PENELITIAN}

Penelitian ini merupakan penelitian deskriptif restrospektif dengan menggunakan data hasil visum et repertum di RSUP Prof. Dr. R. D Kandou Manado periode 2014. Populasi ialah seluruh kasus kekerasan tajam pada kematian di Bagian Ilmu Kedokteran Forensik dan Medikolegal RSUP Prof. Dr. R. D. Kandou Manado. Sampel penelitian ialah total populasi terjangkau periode Januari 2014-Desember 2014. Variabel penelitian ialah jumlah kasus, jenis kelamin, umur, jenis kekerasan tajam, pola luka, dan lokasi luka. Waktu penelitian dilakukan mulai dari bulan September 2015 hingga Desember 2015.

\section{HASIL PENELITIAN}

Penelitian ini dilakukan di Bagian Ilmu Kedokteran Forensik Medikolegal Fakultas Kedokteran Universitas Sam Ratulangi/ RSUP Prof. Dr. R. D. Kandou Manado, Gambar 1 memperlihatkan bahwa pada periode Januari 2014-Desember 2014 didapatkan 27 korban meninggal akibat kekerasan tajam yang diautopsi.

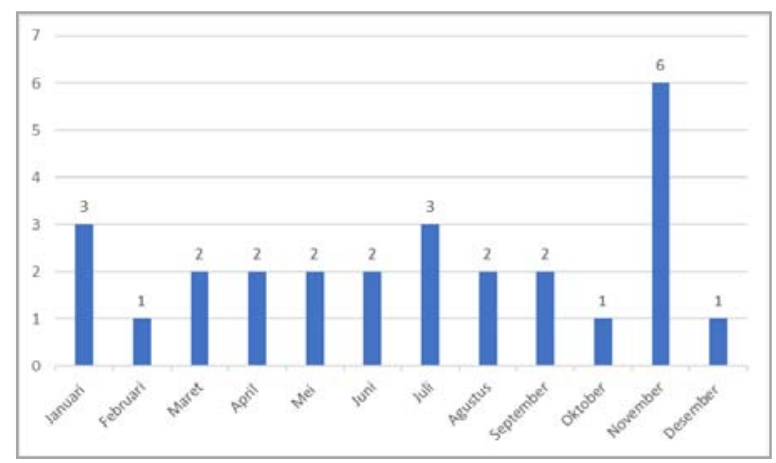

Gambar 1. Distribusi korban akibat kekerasan benda tajam tahun 2014

Tabel 1 memperlihatkan bahwa korban kematian akibat kekerasan benda tajam dalam penelitian ini didominasi oleh rentang umur 21-30 tahun yaitu sebanyak 10 orang $(37 \%)$ dan yang paling sedikit berada pada rentang umur $<50$ tahun yaitu sebanyak 2 orang $(7,4 \%)$.

Tabel 1. Distribusi korban meninggal berdasarkan umur

\begin{tabular}{ccc}
\hline Umur & Jumlah & $\mathbf{( \% )}$ \\
\hline $17-20$ & 5 & 18,5 \\
$21-30$ & 10 & 37,0 \\
$31-40$ & 7 & 26,0 \\
$41-50$ & 3 & 11,1 \\
$>50$ & 2 & 7,4 \\
Total & 27 & 100 \\
\hline
\end{tabular}

Berdasarkan data yang diperoleh dari hasil Visum et Repertum di Bagian Forensik RSUP Prof Kandou tahun 2014, distribusi korban meninggal akibat kekerasan benda tajam menurut jenis kelamin sebanyak 23 orang $(88,4 \%)$ sedangkan jumlah korban dengan jenis kelamin perempuan hanya 3 orang $(11,6 \%)$. 
Gambar 2 memperlihatkan penurunan kekerasan benda tajam sejalan dengan semakin bertambahnya umur. Pada umur $>50$ tahun kasus kematian akibat benda tajam hanya 2 orang (7.4\%) saja.

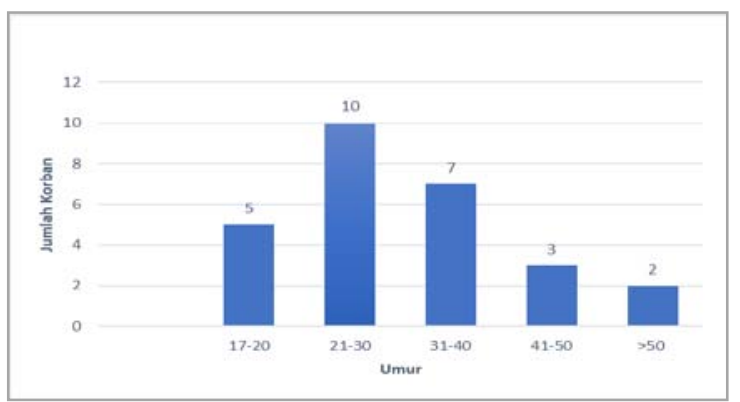

Gambar 2. Kekerasan benda tajam tahun 2014 berdasarkan rentang umur

Tabel 2 memperlihatkan bahwa distribusi korban meninggal berdasarkan jenis luka didominasi oleh jenis luka tusuk dengan jumlah korban sebanyak 20 orang (76,9\%) diikuti oleh luka bacok sebanyak 4 orang $(15,4 \%)$ dan yang paling sedikit ialah jenis luka iris sebanyak 2 orang (7,7\%).

Tabel 2. Distribusi korban meninggal berdasarkan jenis luka

\begin{tabular}{ccc}
\hline Jenis luka & Jumlah & $\mathbf{( \% )}$ \\
\hline Luka tusuk & 20 & 76,9 \\
Luka bacok & 4 & 15,4 \\
Luka iris & 2 & 7,7 \\
Total & 26 & 100 \\
\hline
\end{tabular}

Gambar 3 memperlihatkan distribusi korban meninggal berdasarkan lokasi perlukaan paling banyak pada daerah dada kiri yaitu 11 orang $(42,4 \%)$ diikuti oleh dada kanan 4 orang (15,5\%), punggung kanan 3 orang (11,5\%); yang paling jarang terjadi pada daerah kepala, perut kiri, puncak bahu, dan rongga perut yaitu masing-masing sebanyak 1 orang (3,8\%)

\section{BAHASAN}

Penelitian ini dilakukan di Bagian Ilmu Kedokteran Forensik dan Medikolegal Fakultas Kedokteran Universitas Sam Ratulangi/RSUP Prof. Dr. R. D. Kandou Manado. Pada periode Januari 2014 - Desember 2014 didapatkan 27 korban meninggal aki-

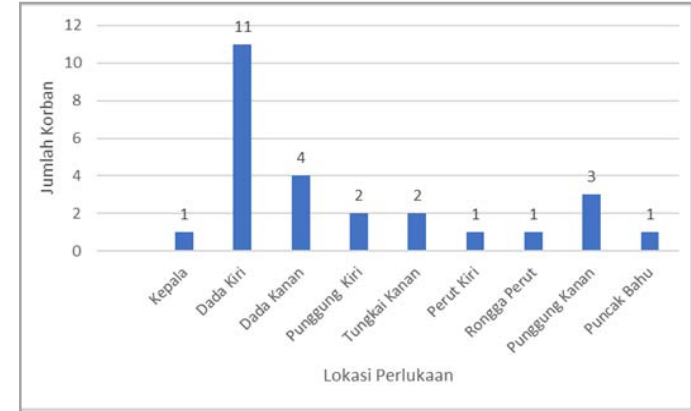

Gambar 3. Distribusi korban meninggal berdasarkan lokasi perlukaan

bat kekerasan tajam yang diautopsi.

Pada penelitian ini korban kematian akibat kekerasan benda tajam didominasi oleh rentang umur 21-30 tahun yaitu sebanyak 10 orang (37\%) dan yang paling sedikit berada pada rentang umur $<50$ tahun yaitu sebanyak 2 orang $(7,4 \%)$. Hasil penelitian ini sejalan dengan penelitian oleh Nerchan et $\mathrm{al}^{5}$ yang menjelaskan bahwa korban kematian akibat kekerasan benda tajam berada pada rentang umur 20-30 tahun yaitu sebanyak 13 orang. Hal ini menunjukkan bahwa sebagian besar korban akibat benda tajam berada pada usia produktif. Pada usia dengan rentang 17-20 tahun hanya terdapat 5 korban $(18,5 \%)$ yang meninggal akibat kekerasan dengan benda tajam.

Pada penelitian ini pola grafik yang mengalami penurunan dengan semakin bertambahnya umur (Gambar 2). Pada umur $>50$ tahun kasus kematian akibat benda tajam hanya 2 orang $(7,4 \%)$ saja. Hal ini diduga karena semakin bertambahnya umur, pemikiran seorang semakin dewasa dan lebih bijak dibandingkan dengan umur yang maish muda. Kematian akibat benda tajam biasanya disebabkan oleh perkelahian atau selisih pendapat yang pada akhirnya menyebabkan pembunuhan menggunakan benda tajam.

Berdasarkan data yang diperoleh dari hasil Visum et Repertum di Bagian Forensik RSUP Prof. Dr. R. D. Kandou tahun 2014, distribusi korban meninggal akibat kekerasan benda tajam berdasarkan jenis kelamin didominasi oleh pria dengan jumlah korban sebanyak 23 orang $(88,4 \%)$ sedangkan korban dengan jenis kelamin 
perempuan hanya 3 orang $(11,6 \%)$. Hal ini sesuai dengan data dari Badan Pusat Statistik (BPS) tahun 2013 yang menyatakan bahwa komposisi penduduk korban kejahatan selama periode tahun 2010-2012 pada setiap provinsi secara umum serupa dengan komposisi secara nasional. Hampir semua provinsi jumlah dan persentase penduduk laki-laki korban kejahatan salah satunya karena kekerasan benda tajam lebih besar dari penduduk perempuan. Mayoritas penduduk yang menjadi korban kejahatan ialah penduduk laki-laki dan sebagian besar di antaranya ialah penduduk dewasa. Perkembangan jumlah dan persentase penduduk korban kejahatan selama periode tahun 2010-2012 terjadi penurunan dari tahun ke tahun. Hal ini terjadi pada semua kelompok penduduk, baik penduduk lakilaki, perempuan, dewasa, maupun anakanak. $^{6}$

Pada penelitian ini didapatkan distribusi korban meninggal berdasarkan jenis luka didominasi oleh jenis luka tusuk dengan jumlah korban sebanyak 20 orang (76,9\%) diikuti oleh luka bacok sebanyak 4 orang (15,4\%) dan yang paling sedikit ialah jenis luka iris sebanyak 2 orang $(7,7 \%)$.

Luka tusuk adalah salah satu jenis luka yang disebabkan oleh penetrasi benda tajam atau runcing pada tubuh. Benda yang digunakan dapat berupa pisau, pecahan kaca, pecahan gelas, gunting, garpu, jarum dan lain sebagainya. Jenis luka ini banyak ditemukan pada kasus pembunuhan. Ukuran dan bentuk dari luka tusuk pada kulit tergantung pada sifat dan jenis benda tajam, arah tusukan, menggerakan pisau pada luka, pergerakan individu yang ditusuk, dan keadaan relaksasi atau kontraksi dari kulit. ${ }^{7}$ Kedalaman luka yang dibentuk oleh luka tusuk dapat kurang, sama atau melebihi panjang benda yang digunakan. Panjang luka yang terbentuk dapat lebih pendek, sama, atau lebih panjang dari benda yang digunakan. Sudut luka yang dibentuk pada luka tusuk biasanya tajam, tanpa absrasi atau konsusio. Jumlah sudut lancip yang dibentuk pada luka tusuk dapat menunjukkan perkiraan benda penyebabnya, missalnya pisau bermata satu atau bermata dua.
Pada luka tusuk yang disebabkan oleh pisau bermata satu biasanya salah satu sudut luka lancip dan yang lain tumpul. Luka tusuk dengan kedua sudut lancip biasanya disebabkan oleh pisau bermata dua. Pisau bermata satu dapat membentuk sudut lancip pada kedua sudut luka jika hanya bagian ujung benda saja yang menyentuh kulit. Kulit disekitar luka biasanya tidak menunjuukan tanda luka lecet atau memar, kecuali bila bagian gagang ikut membentuk kulit. Jika terdapat banyak luka tusuk pada tubuh seseorang, perkiraan panjang dan lebar mata pisau dapat diperoleh dengan memerika semua luka tersebut ${ }^{7}$.

Luka iris disebabkan oleh benda tajam yang ditekan dengan kekuatan relatif ringan kemudian digeserkan sepanjang kulit ${ }^{8}$. Luka iris dapat ditemukan pada kasus pembunuhan maupun bunuh diri. Kasus pembunuhan yang disertai perlawanan, dimana luka iris dapat ditemukan sebagai luka tangkis yang diakibatkan oleh gerakan menangkis untuk menghindari benda tajam yang diarahkan pada korban ${ }^{9}$ Pada kasus bunuh diri, luka iris dapat ditemukan sebagai luka percobaan. Hal ini yang merupakan luka khas pada kasus bunuh diri yang menggunakan benda tajam. Penelitian sebelumnya oleh Humsona ${ }^{10}$ menyimpulkan bahwa penggunaan benda tajam merupakan salah satu cara yang ditempuh korban untuk melukai tubuhnya

Hasil penelitian ini mendapatkan bahwa distribusi korban meninggal berdasarkan lokasi perlukaan paling banyak dialami pada daerah dada kiri yaitu sebanyak 11 orang (42,4\%) diikuti oleh dada kanan sebanyak 4 orang (15,5\%), punggung kanan sebanyak 3 orang $(11,5 \%)$ dan paling jarang terjadi pada daerah kepala, perut kiri, puncak bahu, dan rongga perut yaitu sebanyak 1 orang (3,8\%). Dada kiri menjadi lokasi paling banyak terjadi kasus pembunuhan akibat benda tajam dikarenakan letak jantung berada di sebelah kiri. Jantung merupakan organ vital manusia yang memompa darah keseluruh tubuh. Menusukkan benda tajam di aera jantung akan membuat korban lebih cepat menga- 
lami kelumpuhan dan langsung meninggal. Hal ini diduga menjadi salah satu alasan lokasi penusukan benda tajam didominasi oleh lokasi di dada sebelah kiri. Selain itu, bila pelaku bukan bertangan kidal maka tusukan yang dilakukan ialah dengan menggunakan tangan kanan. Pada posisi ebrhadapan maka tusukan dengan tangan kanan akan mengenai dada kiri korban.

Petunjuk dari luka tusuk sering dianggap sebagai suatu masalah pembunuhan terutama dalam persidangan, yang mengarah pada rekonstruksi pengadilan.

Hasil penelitian ini sejalan dengan penelitian dari Putri $^{7}$ yang menyatakan bahwa pola luka terbanyak ialah luka tusuk. Putri $^{7}$ mendapatkan distribusi umur korban umumnya dari kalangan remaja dan dewasa (15-45 tahun) sedangkan distribusi jenis kelamin korban umumnya laki-laki. Lokasi luka kekerasan tajam terbanyak ialah bagian punggung dan wajah. Senjata tajam yang paling sering digunakan ialah pisau, diikuti oleh kaca, dan parang.

\section{SIMPULAN}

Berdasarkan hasil penelitian ini dapat disimpulkan bahwa korban meninggal akibat kekerasan tajam di Bagian Ilmu Kedokteran Forensik dan Medikolegal Fakultas Kedokteran Universitas Sam Ratulangi/ RSUP Prof. Dr. R. D. Kandou Manado periode Januari 2014-Desember 2014 yang terbanyak ialah laki-laki, kategori usia 2130 tahun, dengan luka tusuk pada dada kiri.

\section{DAFTAR PUSTAKA}

1. Abdussalam HR, Desasfuyanto A. Buku Pintar Forensik. Jakarta: PTIK PRESS, 2014.
2. Manado Post Online 12 Juli 2014. Kasus Sajam di Manado "Mencekam". [cited 2014 Sept 17]. Available from: manadopostonline.com: http://manadopostonline.com/read/2014 /07/12/Kasus-Sajam-di-ManadoMencekam/4039

3. Bibliography Manado Tribun News Online 11 September 2013. Kasus Sajam Dominan Orang Muda. [cited 2014 Sept 17]. Available from: manado. tribunnews.com: http://manado.tribun news.com/2013/09/11/kasus-sajamdominan-orang-muda

4. Wilham D. Ilmu kedokteran forensik [Thesis]. Jakarta: Fakultas Kedokteran Universitas Indonesia; 1997.

5. Nerchan E, Mallo JF, Mallo NTS. Pola luka pada kematian akibat kekerasan tajam di Bagian Ilmu Kedokteran Forensik dan Mediko-legal RSUP Prof. Dr. R. D. e-Kandou Manado periode 2013. eCliniC. 2015;3(2):640-5.

6. Badan Pusat Statistik (BPS). 2013. Statistik Kriminal 2013. BPS: ISSN 2089.5291

7. Putri FH. Gambaran pola luka kekerasan tajam di Bagian Forensik RSUP Dr. M. Djamil Padang Tahun 2016-2017 [Diploma thesis]. Padang: Universitas Andalas; 2018.

8. Idries AM, Tjiptomartono A. Penerapan Ilmu Kedokteran Forensik dalam Proses Penyidikan. Jakarta: Sagung Seto, 2008.

9. Dahlan S. Ilmu Kedokteran Forensik Pedoman Bagi Dokter dan Penegak Hukum (3rd ed). Semarang: badan Penerbit Universitas Diponegoro, 2004; p. 34-9.

10. Humsona R. Bunuh diri: faktor-faktor penyebab, cara yang ditempuh dan respons komunitas. J Sosiolog 2004; 17(1):59-66. 